\title{
ЛЮБОВНІ ЗАМКИ ЯК ЕЛЕМЕНТ МОВНОГО ЛАНДШАФТУ
}

Белей Л. Л. Любовні замки як елемент мовного ландшафту.

У статті здійснено соціолінгвістичний аналіз практики закріплення так званих любовних замків у контексті формування мовного ландшафту. Дослідження виконано на матеріалі, зібраному на ужгородському пішохідному мості (75 написів на любовних замках). Розглянуто мовні та стилістичні особливості написів.

Ключові слова: соціолінгвістика, мовний ландшафт, мультилінгвізм, глобалізація, любовні замки.

Белей Л. Л. Любовные замки как элемент языкового ландшафта.

В статье представлен социолингвистический анализ практики установки любовных висячих замков в контексте формирования языкового ландшафта. Исследование выполнено на материале, собранном на пешоходном мосте в г.Ужгороде (75 надписей на любовных висячих замках). Рассмотрено языковые и стилистические особенности подписей.

Ключевые слова: социолингвистика, языковый ландшафт, мультилингвизм, глобализация, любовные висячие замки.

Beley L. L. The lovelocks as element of linguistic landscape.

The article is devoted to the sociocultural practice of so called lovelocks. This topic has been explored through the perspective of linguistic landscape. The exploration has been conducted on the material of a Uzhhorod bridge (75 lovelocks). We described lingual and stylistic peculiarities of the lovelock texts.

Key words: sociolinguistics, linguistic landscape, multilingualism, globalization, lovelocks.

За визначенням Лондрі-Бурі [2, с. 25], термін «мовний ландшафт» «стосується видимості мов у публічних і комерційних знаках на певній території чи у певному регіоні». У цій концепції йдеться про «мову дорожніх транспарантів, рекламних біл-бордів, назв вулиць, топонімів, вивісок магазинів, знаків на урядових будівлях тощо» [ibid.]. Однак текст як елемент мовного ландщафту нерідко має інші локації, не зазначені у визначенні Лондрі-Бурі. До цього переліку можна додати рекламу, оголошення, епітафії, графіті тощо. Одним із таких виявів мовного ландшафту в Україні можна також вважати так звані любовні замки. 
Сама традиція вішати любовні замки в Україні порівняно нова і має близько п'яти років. Суть іï полягає у тому, що закохані встановлюють навісні замки, як правило, на мостах, аби в такий спосіб засвідчити щирість і незламність своїх почуттів. На замках, як правило, роблять певний запис, який, власне, i можна трактувати як елемент мовного ландшафту. На відміну від інших неформальних об'єктів мовного ландшафту, любовні замки зазвичай розміщують на мостах, а отже, у полі зору багатьох мовців. Тому, на нашу думку, любовні замки не належать до маргінальних проявів мовного ландшафту.

Традиція вішати мовні замки не належить до регіональних. За дослідженнями, вона популярна на всіх континентах. Традиція навісних любовних замків поширена в Китаї, Угорщині, США, Росії, Італії, Німеччині, Франції, Уругваї та ін. [3] «Шеартревел» [4] традиція виникла завдяки роману «Tre metri sopra il cielo» Федеріко Мочча, опублікованому у 1992 році. Головні герої цього роману увіковічнили свої почуття, закріпивши любовний замок на Понте Веччіо у Флоренції. Хоча, за іншими джерелами, ця традиція може також походити з Угорщини (у Печі вішали замки ще у 80-х) або з Китаю, де на певних відтинках Китайської стіни також практикували подібну традицію [3]. Попри різні версії походження, зараз ця традиція набула глобального поширення. Сьогодні можна знайти цілі ресурси, які збирають матеріали про любовні замки по всьому світу [5].

Любовні замки належать до нерегульованих елементів мовного ландшафту. На відміну від вивісок та реклами, текст любовних замків ніяк не регулюється органами влади, а отже, може слугувати за об'єктивне відображення мовної активності тих, що його написали. Анонімність також сприяє цьому. Для порівняння, графіті як елемент мовного ландшафту відображають мовну активність досить вузької соціальної групи райтерів. Окрім того, мовна активність райтерів карається законом. Натомість практика розміщення любовних замків має значно ширше соціальне поле. По-перше, з точки зору гендеру, у цій практиці бере участь завжди рівна кількість осіб обох статей. По-друге, традиція вішати любовні замки практикується людьми різного віку - на порах першого кохання і аж до шлюбу, а отже, переважно від підліткового віку і до 30 років.

В Україні традиція любовних замків порівняно нова, хоч уже й досить поширена. Ними обвішаний Міст закоханих у Києві, Тещин міст в Одесі, пішохідний міст в Ужгороді та багато інших мостів. Це дослідження проведено головним чином на матеріалі, зібраному в Ужгороді у квітнітравні 2010 року.

Текст любовного замка, зазвичай, має стереотипний характер, а його загальну схему можна звести до такої формули: $\mathrm{X}(+) \mathrm{Y}$ (= love, любов і т.д. [графічне зображення сердечка]) дата встановлення навісного замка (додатковий текст). $\mathrm{X}$ та $\mathrm{Y}$ - це імена хлопця та дівчини. На замках 
пишуться тільки імена, як правило, розмовні варіанти, часто емоційно марковані, а також прізвиська або ініціали імен. Тільки в одному випадку ми зафіксували прізвище. Елементи в дужках зустрічаються не на всіх любовних замках, але їх можна вважати за тенденційні. У 50 з 75 зафіксованих нами прикладів першим пишеться ім'я хлопця (якщо не враховувати абревійованих написів, у яких важко розшифрувати імена).

За мовною ознакою зафіксовані нами ужгородські любовні замки (75) можна поділити на такі групи: 1) україномовні (46): а) власне україномовні (29); б) україномовні 3 англомовними елементами (3); в) україномовні, омографічні з російськомовними (14); 2) російськомовні (21); 3) угорськомовні (7); 4) англомовні (1).

В окремих написах (омографічна група) важко однозначно встановити мову тексту, оскільки його компоненти 3 лексичного та правописного погляду можна витлумачити як україно- або російськомовні. Напр.: Юра + Таня, Ваня Яна, Шура + Женя, Ксюха + Женя, Танька + Ванька, Артур + Жанна тощо. Угорськомовні записи прикметні тим, що в них ми зафіксували російськомовні 3 походження іменні варіанти, наприклад, Sztyopu та Vászja, що вживаються замість очікуваних угорських Pista, Pisti від István [1, c. 99] та Laci від László [1, с. 125], що свідчить про антропонімійну інтерференцію українського (російського) антропонімікону в угорський.

У всіх мовних групах імена мають приблизно однакове формальне вираження. Часто вживаються розмовні та емоційно марковані варіанти імен (Вася, Славік, Саша, Міша, Толік, Коля, Лёша, Вова, Одри, Іра, Дашка, Оксанка, Meli, Уля, Ксюха, Лида, Вика та ін.) Характерною для україномовних записів є російська демінутивна модель (пор.: Міша, Славік тощо). За частотою вживання прізвиська явно поступаються особовим іменам, тому ми зафіксували лише поодинокі випадки вживання одиниць цього антропонімного класу в написах на любовних замках. Наприклад: кim + киця, Keri, Vadoc (героїня коміксів) тощо. Прикметно, що в російськомовній групі написів на любовних замках ми не зафіксували англомовних вкраплень. Також ми не знайшли змішаних, українськоросійських написів. Натомість в україномовних написах на замках є певна група з англомовними елементами. Наприклад, Інна Baня love, Biкa + Keri = love, Коля Meli forever. (Meli - це демінутив від імені Меліта). Iз 75 прикладів тільки в одному зазначалося прізвище пари: Без базара говорю: Люба! Я тебя люблю! Хотняк+Хотнячка! 14.02.10.

Щодо доповнення запису датою, то ми зафіксували 16 таких прикладів. В одному прикладі записано дві дати: Cmenaн + Лідочка 27.06.09 13.12.09. Імовірно, йдеться про дату знайомства і дату шлюбу або закріплення замка.

Супровідний текст імен закоханих ми зафіксували в 16 випадках. Його записують, щоб наголосити на силі почуттів. Типовими є англійські 
фрази «love» та «forever» (4). У записах іншими мовами використовуються еквіваленти: пор.: Вика Рома любовь навсегда; Назавжди разом!!! Тарас $i$ Аліна 03.09.2009 p. та угорськ. István Zsuzsa 09.12.09 szeretlek. Часом використовуються розбудовані тексти: Ангеліка + Саша На дві душі - одне дихання 06.03.2010. В одному випадку ми зафіксували супровідний запис латиною: Вася Яна 08.08.2009 p. Volente deo. Два ужгородські замки, із зафіксованих нами, закріплені в день весілля: Михайло та Надія до дня весілля 29.08.2009 р.; Евгений и Юлия В день свадьбы 11.07.2009. Два замки містили текст без імен закоханих Віра Надія Любов, I love You; один замок був приурочений до дня народження Леля $C$ Днем рождения. Один замок, очевидно, увіковічнював дружні стосунки трьох осіб - Таня Cmena Ростик.

Ужгородські любовні замки відображають особливості місцевої мовної спільноти. Серед іiі особливостей можна виділити: 1) постколоніальну спадщину (російськомовні записи); 2) етнічну гетерогенність мовної спільноти (наявність угорськомовних написів); 3) глобалізаційні впливи, головним чином поп-культури (англомовні елементи), причому характерно, що глобалізаційні впливи в Ужгороді поширюються головним чином на україномовні написи. 3 матеріалу любовних замків можна також виокремити антропонімічні моделі: особливості демінутивізації тощо.

1. Gajdos Z. Utónévlexikon / Z. Gajdos. - Budapest, 2007.

Література

2. Landry R., Bourhis R. Y. Linguistic Landscape and Ethnolinguistic Vitality / R. Landry, R. Y. Bourhis // Journal of Language and Social Psychology, Vol. 16, No. 1, Universite du Quebec, Montreal, 1997, pp. 23-49

3. http://en.wikipedia.org/wiki/Love_padlocks

4. http://sharetravel.com.ua/28479.html

5. http://lovelock.ru 